explain why nature requires the existence of two highly similar peptides. If chemical agonists or antagonists could be targeted - for example, by direct skin application - interesting therapeutic possibilities would be raised.

\section{DOMHNALL J O'HALLORAN Research Fellow}

S R BLOOM

Division of Endocrinology and Metabolism,

Professor of Endocrinology

Department of Medicine,

Hammersmith Hospital

London W12 0NN

1 Emeson RB, Hedjran F, Yeakley JM, Guise JW, Rosenfeld MG. Alternative production of calcitonin and CGRP mRNA is regulated at the calcitonin-specific splice acceptor. Nature 1989;341:76-80

2 Kittur SD, Hoppener JWM, Antonarakis SE. et al. Linkage map of the short arm of human chromosome 11: location of genes for catalase, calcitonin and insulin-like growth factor II. Proc Natl Acad Sci USA 1985;82:5064-7.

3 Rosenfeld MG, Mermod JJ, Amara SG, et al. Production of a novel neuropeptide encoded by the calcitonin gene via tissue specific RNA processing. Nature 1983:304:129-35.

4 Morris HR, Panico M, Etienne T, Tippins J, Girgis SI, MacIntyre I. Isolation and characterisation of human calcitonin gene-related peptide. Nature 1984:308:746-8.

of human calcitonin gene-related peptide. Nature 1984:308:746-8.
Alevizaki M, Shiraishi A, Rassool FV, Ferrier CJM, MacIntyre I, Legon S. The calcitonin like sequence of the beta CGRP gene. FEBS Letl 1986;206:47-52

6 Steenbergh PH, Hoppener JWM, Zandberg J, Lips CJM. Jansz HS. A second human calcitonin/ CGRP gene. FE BS Lett 1985;183:403-7.

7 Hoppener JWM, Steenbergh PH, Zandberg J, et al. The second human calcitonin/CGRP gene is located on chromosome 11. Hum Genet 1985;70:259-63.

8 Zaidi M, Breimer LH, Macintyre I. Biological peptides from the calcitonin gene. QI Exp Physiol 1987;72:371-408

9 Goodman EC, Iverson LL. Calcitonin gene-related peptide: novel neuropeptide. Life Sci 1986;38:2169-78

10 Amara SG, Arriza JL, Leff SE, Swanson LW, Evans RM, Rosenfeld MG. Expression in brain of a messenger RNA encoding a novel neuropeptide homologous to calcitonin gene-related peptide. Science 1985;229:1094-7.

11 Tschopp FA, Henke H, Petermann JB, et al. Calcitonin gene-related peptide and its binding sites in the human central nervous system and pituitary. Proc Nat Acad Sci USA 1985;82:248-52.

12 Gibson SJ, Polak JM, Giaid A, et al. Calcitonin gene-related peptide is expressed in sensory ganglia and also in spinal motorneurones in man and rat. Neurosci Lett 1988;91:283-8.

13 Wimalawansa SJ, Morris HR, Etienne A, Blench I, Pancio M, MacIntyre I. Isolation, purification and characterisation of $\beta$-h CGRP from human spinal cord. Biochem Biophys Res Commun

14 Mulderry PK, Ghatei MA, Rodrigo K, $t$ al. Calcitonin gene-related peptide in cardiovascular tissues of the rat. Neuroscience 1985:14:9474-5

15 Wharton J, Gulbenkian S, Mulderry PK, tt al. Capsaicin induces a depletion of calcitonin generelated peptide immunoreactive nerves in the cardiovascular system of the guinea pig and rat. J A uton Nerv Syst 1986;16:298-309.

16 Wanaka A, Matsuyama T, Yoneda S, et al. Origins and distribution of calcitonin gene-related peptide-containing nerves in the wall of the cerebral arteries of the guinea pig with special reference to co-existence with substance P. Cell Mol Biol 1987;33:201-9.

17 Mulderry PK, Ghatei MA, Spokes RA, et al. Differential expression of alpha-CGRP and betaCGRP by primary sensory neurons and enteric autonomic neurons of the rat. Neuroscience 1988:25:195-205.

18 Petermann JB, Born $\mathrm{W}$, Chang J-Y, Fischer JA. Identification in the human central nervou system, pituitary, and thsroid of a novel calcitonin gene-related peptide, and partial amino acid sequence in the spinal cord. 7 Biol Chem 1987;262:542-5.

19 Tiller-Borcich JK, Capili H, Gordan (GS. Human brain calcitonin gene-related peptide (CGRP) is concentrated in the locus caeruleus. Neuropeptides 1988:11:55-61.

20 Henke H, Sigrist S, Lang W, Schneider J, Fisher JA. Comparison of hinding sites for the calcitonin gene-related peptides I and II in man. Brain Res 1987;410:404-8.

21 Inagaki S, Kito S, Kubota Y, Girgis S, Hillyard CJ, MacIntyre I. Autoradiographic localisation of calcitonin gene-related peptide binding sites in human and rat brain. Brain Res 1986;374:287-98

22 Jonas V, Lin CR, Kawashima E, et al. Alternative RNA processing events in human calcitonin calcitonin gene-related peptide gene expression. Proc Natl Acad Sici CS.A 1988;82:1994-8.

23 Hoppener JW, Steenberg PH, Slebos RJ, et al. Expression of the second calcitonin/calcitonin generelated peptide gene in Ewing sarcoma cell lines. F Clin Eindocrinol Metab 1987;64:809-17.

24 Edbrooke MR, Parker D, McVey JH, et al. Expression of the human calcitonin/CGRP gene in lung and thyroid carcinoma. Embryo foumal 1985;4:715-2t.
25 Kim S, Morimoto S, Kawai Y, Onishi T, Ogihara T. Circulating levels of calcitonin gene-related peptide in patients with medullary thyroid carcinoma. F Clin Chem Clin Biochem 1989;27:423-7. 26 Girgis SI, MacDonald DWR, Stevenson JC, et al. Calcitonin gene-related peptide: potent vasodilator and major product of calcitonin gene. Lancet 1985;ii: 14-7.

27 Wimalawansa SJ, Morris HR, MacIntyre I. Both alpha- and beta-calcitonin gene-related peptide are present in plasma, cerebrospinal fluid and spinal cord in man. 7 Mol Endocrinol 1989:3: $247-52$.

28 Stevenson JC, Macl)onald DWR, Warren RC, Booker MW, Whitehead MJ. Increased concentration of circulating calcitonin gene-related peptide during normal pregnancy. BM7 1986;293: 1329-30.

29 Foord SM, Craig RK. Isolation and characterisation of a human calcitonin gene-related receptor. Eur J Biochem 1987:170:373-9.

30 Denis-Donini S. Expression of dopaminergic phenotypes in the mouse olfactory bulb induced by the calcitonin gene-related peptide. Nature 1989;339:701-3.

31 Takami K, Kawai Y, Shio Saka S, et al. Immunohistochemical evidence for the coexistence of calcitonin gene-related peptide and choline acyltransferase-like immunoreactivity in neurons of the rat hypoglossal, facial and ambigus nuclei. Brain Res 1985;328:386-9.

$32 \mathrm{New}$ HV, Mudge AW. Calcitonin gene-related peptide regulates muscle acetylcholine receptor ynthesis. Nature 1986;323:809-11

33 Fontaine B, Klarsfeld A, Changeux J-P. Calcitonin gene-related peptide and muscle activity regulate acetylcholine receptor alpha-subunit mRNA levels by distinct intracellular pathways. fCill Biol 1987;105:1337-42.

34 Takamori M, Yoshikawa HJ. Effect of calcitonin gene-related peptide on skeletal muscle via specific binding sites and G protein. F Neurol Sci 1989;90:99-109.

35 Gibson SJ, Polak JM, Katagiri T, et al. A comparison of the distribution of eight peptides in spinal cord from normals and cases of motor neurone disease with special reference to Onuf's nucleus. Brain Res 1988:474:255-78.

36 Girgis SI, Yates CM, Fink G, MacIntyre I. Calcitonin gene-related peptide and calcitonin immunoreactivity in brain and spinal cord in Alzheimer-type dementia. F Neurol Sci 1990;99: 69-74.

37 Nelson MT, Huang Y, Brayden JE, Hescheler J, Standen NB. Arterial dilations in response to calcitonin gene-related peptide involves activation of K' channels. Nature 1990;344:770-3.

38 Bunker CB, Terenghi G, Springall DR, Polak JM, Dowd PM. Deficiency of calcitonin gene-related peptide in Raynaud's phenomenon. Lancet 1990;336:1530-3.

39 Unger WG, Terenghi G, Ghatei MA, et al. Calcitonin gene-related polypeptide as a mediator of the neurogenic ocular injury response. F Ocul Pharmacol 1985;2:189-99.

40 Fuller RW, Conradson TB, Dixon CM, Crossman DC, Barnes PJ. Sensory neuropeptide effects in human skin. Brf Pharmacol 1987;92:781-8.

41 Williams G, Cardoso H, Ball JA, Mulderry PK, Cooke E, Bloom SR. Potent and comparable vasedilator actions of $\mathrm{A}$ - and $\mathrm{B}$-calcitonin gene-related peptide on the superficial subcutaneous vasculature of man. Clin Sci 1988:75:309-13.

42 Rogers DF, Belvisi MG, Aursudkij B, Evans TW, Barnes PJ. Effects and interactions of sensory neuropeptides on airway microvascular leakage in guinea-pigs. Br f Pharmacol 1988:95:1109-16.

43 Brain SD, Williams TJ. Inflammatory oedema induced by synergism between calcitonin generelated peptide (CGRP) and mediators of increased vascular permeability. Br $\mathrm{F}$ Pharmacol 1985;86:655-60.

H Coupe MO, Mak JCW, Yacoub M, Oldershaw PJ, Barnes PJ. Autoradiographic mapping of calcitonin gene-related peptide receptors in human and guinea pig hearts. Circulation 1990;81:

45 McEwan J, Larkin S, Davies G, el al. Calcitonin gene-related peptide: a potent dilator of human epicardial coronary arteries. Circulation 1986;74:1243-7.

46 Uren NG, Davies GJ. Human alpha calcitonin gene-related peptide improves exercise workload to ischaemia and dilates stenosis of the epicardial coronary artery [Abstract]. Eur Heart $f$ 1990;11(suppl): 1070 .

47 Johnson $\mathrm{FG}$, Bell BA, Robertson IAJ, et al. Effect of calcitonin gene-related peptide on postoperative neurological deficits after subarachnoid hacmorrhage. Lancet 1990;335:869-72.

$48 \mathrm{McC}$ (rmack DG, Mak JCW, Coupe MO, Barnes PJ. Calcitonin gene-related peptide vasodilation of human pulmonary vessels. F Appl Physiol 1989;67:1265-70.

49 Palmer JBD, Cuss FMC, Mulderry PK, et al. Calcitonin gene-related peptide is localised to human airway nerves and potently constricts human airway smooth muscle. Br 7 Pharmacol 1987:91: 95-101

50 Barnes PJ. Neuropeptides in human airways: function and clinical implications. Am Rev Respir Dis 1987; 136:S77-83.

51 Springall DR, Collina G, Barer G, Suggett AJ, Bee D, Polak JMI. Increased intracellular levels of calcitonin gene-related peptide-like immunoreactivity in pulmonary endocrine cells of hypoxic rats. I Puthol 1988:155:259-67.

52 Leighton B, Cooper (IJS. Pancreatic amylin and calcitonin gene-related peptide cause resistance to insulin in skeletal muscle in vitro. Nature 1988;335:632-5.

53 Leighton B, Foot FA, Cooper GJS, King JM. Calcitonin gene-related pentide-1 (CGRP-1) is a potent regulator of glycogen metabolism in rat skeletal muscle. FLBS Lett 1989;249:357-61.

54 Brown MJ, Morice AH. Clinical pharmacology of vasodilator peptides. $\mathcal{I}$ Cardiovasc Pharmacol 1987;10 (suppl 12;:82-7.

55 Struthers AD, Brown MJ, MacDonald DWR, et al. Human calcitonin gene-related peptide: a potent endogenous vasodilator in man. Clin Sci 1986;70:389-93.

56 Beglinger C, Born W, Hilderbrand P, et al. Calcitonin gene-related peptides I and II and calcitonin distinct effects on gastric acid secretion in humans. Gastroenterology 1988;95:958-65.

\title{
Multiple births: too often a disaster
}

\section{The buck stops at those treating infertility}

Although much is known about twin pregnancy -its effects on maternal health and perinatal outcome and its costs to families and society-little is known about higher order births. To fill this gap the Office of Population Censuses and Surveys set up a national study of triplet and higher order births.' Its aim was to survey all such births in the United Kingdom over five years (1980 and 1982-5).

Interest in the topic was aroused by the increasing number of multiple deliveries after treatment of subfertility, and the report documents that $36 \%$ of mothers of triplets and $70 \%$ of mothers of quadruplets and above had received drugs for induction of ovulation. Worryingly, many parents receiving such treatments had not been warned and were therefore unprepared for such outcomes. Most treatment for infertility is provided in the private sector, whose workers do not have to confront the consequences for the NHS and the community of caring for women with multiple births and their children.

Although not so sure about twin pregnancies, ${ }^{2}$ obstetricians clearly favour routine hospital admission for mothers of triplets and quadruplets even without complications. The 
survey found that about half the mothers of triplets and three quarters of those expecting quadruplets were initially admitted for rest alone. Women varied in their views about such a policy, some feeling reassured, others feeling anxious and stressed - particularly about the effects on their families. The report highlighted the costs to the NHS and their families of admission, an intervention without evidence of benefit.

Most reviews of managing triplet pregnancy concentrate on relating outcome to the mode of delivery. ${ }^{3-5}$ No consensus, however, has been reached about the optimum method as controlling for confounding variables, particularly gestational age, is difficult. In several studies only those women whose labours began very early were allowed to deliver vaginally. Although not helping to resolve this controversy, the survey by the Office of Population Censuses and Surveys highlighted the need for systematic evaluation of caesarean section. It also suggested open discussion with parents about the mode of delivery, likely neonatal problems, and possible outcomes.

Multiple births are likely to be more complicated and to occur at even earlier gestational ages than twins. Birth weights in this survey were similar to those described 40 years agothat is, the more fetuses present the more likely they were to weigh less than $1500 \mathrm{~g}$ at birth. ${ }^{6}$ These very low birthweight infants require long periods of neonatal intensive care, which puts parents under severe strain. The report considers that liaison between hospitals, primary care, and social services could be improved. Better support - both advice and practical aid - could be provided, and this needs coordinating by someone other than the parents, which usually occurs at present.

About $5 \%$ of triplets in this review had a congenital malformation. (Although high, this figure is not directly comparable with national data.) Also of concern is the increased prevalence of cerebral palsy and general ill health and disability in childhood. Because of the design of the follow up questionnaire and responses the authors believe that they have underestimated the size of developmental problems. They call for further long term follow up studies to assess physical and mental handicap and educational problems.

Finally, the cost to the NHS is calculated: each set of twins costs $£ 5000$, each set of triplets $£ 12000$, and each set of quadruplets $£ 25000$. Some $60 \%$ of the estimated cost is for neonatal care, and $20 \%$ is for antenatal care in hospital. The cost to parents of having three or more children at once is greater than having them in succession.

Selective reduction in the first trimester has been suggested as an alternative management in higher order multiple births but raises difficult legal and ethical issues. ${ }^{8}$ Preventing high order multiple pregnancies is clearly the best option given the high costs to mothers, babies, and services. The onus is therefore on those treating infertility to keep multiple births to a minimum.

Senior Lecturer in Obstetrics and Gynaecology,

DORIS M CAMPBELL

University of Aberdeen,

Aberdeen AB9 2ZD

1 Botting BJ, MacFarlane AJ, Price FV, eds. Three, four, and more. A study of triplet and higher order births. London: HMSO, 1990.

2 Hall MH. Rest in hospital and twin pregnancy. Br f Obstet Gynaecol 1990;97:869-71.

3 Campbell DM, MacGillivray I. Management of labour and delivery: higher multiples. In MacGillivray I, Campbell DM, Thompson B, eds. Twinning and twins. Chichester: John Wiley and Sons, 1988:158-60

4 Crowther CA, Hamilton RA. Triplet pregnancy: a 10 year review of 105 cases at Hapore Maternity Hospital, Nigeria. Acta Genet Med Gemellol (Roma) 1989;38:271-8.

5 Lipitz S, Reichman B, Paret C, et al. The improving outcome of triplet pregnancies. Am f Obstet Gynecol 1989;161:1279-84.

6 McKeown T, Record RG. Observations of fetal growth in multiple pregnancy in man. $\mathcal{F}$ Endocrinol 1952;8:386-401.

7 Berkowitz RL, Lynd L, Chitkara U, et al. Selective reduction of multifetal pregnancies in the first trimester. N Engl f Med 1988;318:1043-7.

8 Howie PW. Selective reduction in multiple pregnancy. Legal confusion and ethical dilemmas. BMF $1988 ; 297: 433-4$
Much research into health and disease depends on data collected from many subjects over long periods of time. Primary care is the obvious place to collect these data: general practitioners deal with most episodes of illness and have records of those episodes dealt with elsewhere. Until recently, however, the structure of general practice and the detail of recorded information have militated against such research, ${ }^{1-3}$ except in trained and motivated "spotter" practices. ${ }^{+}$The arrival of computers into general practice brought hopes of improvement. ${ }^{5-7}$

In 1987 the two main suppliers of computers to general practice, VAMP Health and AAH Meditel, offered computers to practices at low cost in return for access to aggregated patient data. (These could be sold to interested parties, pharmaceutical companies being the most obvious customers. ${ }^{8}$ ) Databases covering 1500 general practices and 3 million patients were envisaged, which could be used to examine prescribing habits. Other possibilities existed-for example, monitoring workload, preventive care, ${ }^{9}$ management, and post-prescription events-but recording details of these lay outside the normal contractual obligations.

The early hopes for large databases have not been fulfilled. VAMP's financial difficulties, ending its agreement to purchase aggregated data from practices, brings the viability of these schemes into question. ${ }^{10}$ The main problem, however, has been incomplete recording. On p 766 Jick and colleagues record that in August 1988, when the VAMP scheme had enrolled 1000 doctors, only 75 practices had reached an acceptable standard of recording. Currently only one in three practices is up to standard. ${ }^{11}$ In one winter month in 1989, 89 of 548 Meditel practices recorded no respiratory infections, and a further 26 could not supply data on list size. In those meeting these minimum criteria, influenza was recorded at a rate one quarter of that obtained from the weekly returns to the Birmingham research unit of the Royal College of General Practitioners (p 763). ${ }^{12}$

The poor quality of data is explained by practices consistently recording only what their contracts with the computer suppliers specify. All that are consistently retrievable are patients' ages and addresses, diagnoses resulting in a prescription (only about $70 \%$ of all diagnose ${ }^{13}$ ), and the prescriptions themselves. All other data recorded by practices depend on individual preference, which varies within and among practices. The absence of medical, social, and occupational histories obviously limits the value of the databases for epidemiological research and hypothesis testing.

Perhaps their best use at present (as suggested by the two 